criteria of speciation in the genus Streptomyces; 'Ektachrome' transparencies as aids in Actinomycete classification ; induced mutation and strain selection in some industrially important micro-organisms; morphological studies in the genus Nocardia.

\section{Statistics of Petroleum Products in Britain}

Staristrcs recently issued by the Petroleum Information Bureau on behalf of the Petroleum Industry Advisory Committee reveal that in 1954 , for the first time, the United Kingdom used more than twenty million tons of petroleum products (excluding bunkers for ships engaged in foreign trade). Actual total inland consumption was $21,038,511$ tons-more than two million tons increase on the corresponding figure for 1953. Of this total, nearly six million tons represents motor spirit (including motor benzole); $1 \cdot 3$ million tons burning and vaporizing oils; 1.4 million tons derv fuel ; 6.3 million tons gas, diesel and fuel oils. Consumption of all other petroleum products showed substantial increases over corresponding figures for 1953. Of indigenous materials made available for distribution in the United Kingdom by the industry, motor spirit by low-temperature carbonization and also refined benzole showed increases compared with 1953.

\section{Library of the University of Leeds : Report for 1953-54}

THE annual report of the Librarian of the University of Leeds for the session 1953-54 (pp. 11; Leeds, 1954) records holdings of books and pamphlets totalling 540,770 on June 30,1954 , accessions during the year totalling 13,347 volumes, 2,421 pamphlets and 25,086 periodical parts. Of these, 6,503 volumes and 1,684 pamphlets were presented, while many books and periodicals were obtained by systematic exchange, particularly with the Biblioteca Apostolica. Vaticana, the British Museum, the Library of Congress, Societas Entomologica Fennica and the Universities of Berne, Helsinki, Marburg, Münster and Zurich. The second instalment of the new stack and mezzanine floor has given complete satisfaction both on practical and æsthetic grounds, and it is hoped that the scheme will be completed in the near future by the addition of the two surrounding portions which will bring the new floor to the outer perimeter and make provision for research readers. There was an increase of 5 per cent in cataloguing done during the year; but the position of the Medical Library further deteriorated, and there is now insufficient space for text-books and monographs and the commonly used periodicals. Plans have been made for a small extension of the building which it is hoped will have been undertaken early this year.

Chemistry and Biology of Phospholipids: Symposium in London, Ontario

THe Biochemistry Division of the Chemical Institute of Canada is sponsoring a symposium on phospholipids, to be held in the University of Western Ontario, London, during October 12-13, immediately preceding the meeting of the Canadian Physiological Society. The symposium will consist of two sessions on the following topics: chemistry of phospholipids (chairman, A. M. Wynne, University of Toronto), at which phosphoglycerides, inositol phospholipids and sphingolipids will be discussed; and metabolism and function of phospholipids (chairman, W. R. Bloor, University of Rochester,
New York), at which their biological synthesis, metabolism in vitro, and function will be discussed. Members of the Canadian Physiological Society and others interested may attend the symposium. There will be a registration fee of one dollar. Further information can be obtained from Dr. R. J. Rossiter, Department of Biochemistry, University of Western. Ontario, London, Ontario.

\section{Announcements}

Sir ArNoln HaLI, director of the Royal Aircraft Establishment, Farnborough, since 1951 (see Nature, $168,19 ; 1951)$, is retiring and will join the Hawker Siddeley Group as technical director. He will be succeeded at Farnborough by Mr. G. W. H. Gardner, director-general of technical development (air) at the Ministry of Supply.

THE Council of the Physical Society has made the following special awards for 1956: Guthrie Lecture, Sir Francis Simon; Rutherford Lecture, Prof. P. I. Dee; Duddell Medallist, Prof. J. G. Gaunt ; Charles Vernon Boys Prize, Dr. G. D. Rochester and Dr. C. C. Butler.

The Executive Council of the Commonwealth Agricultural Bureaux has elected Mr. J. E. C. Coventry, representing the Federation of Rhodesia and Nyasaland, as its chairman, in succession to Mr. W. F. C. Morton, who represented the Union of South Africa. Mr. A. I. Perera, representing Ceylon, has succeeded Mr. Coventry as vice-chairman.

Dr. Helen Marguerite Murr-Wood, principal scientific officer in the Department of Geology, British Museum (Natural History), has been appointed deputy keeper in that Department. Dr. Muir-Wood is a graduate of the University of London (Bedford College and University College) and went to the British Museum (Natural History) in 1922. She was given charge of the Brachiopoda, on which group she has published a number of monographs and papers.

DR. T. A. M. NASH, deputy director of the West. African Institute for Trypanosomiasis Research, Kaduna, Northern Nigeria, has been appointed director of the Institute, the appointment dating from October 17, 1954, when Colonel H. W. Mulligan retired. Dr. Nash, who is well known for his work on the ecology and control of tsetse flies, has been connected with the Institute as chief entomologist and deputy director since its inception in 1948; he has been engaged in tsetse work since his first appointment to Tanganyika Territory in 1927.

Ir has been decided to change the name of the Royal Sanitary Institute; it will be known in future as the Royal Society for the Promotion of Health.

THE Chemical Research Laboratory (Department of Scientific and Industrial Research), Teddington, Middlesex, is having open days during September 27-29. Applications for invitations should be sent to the Director not later than August 31; those already on the mailing list need not re-apply.

Tre Institution of Chemical Engineers and the Society of Instrument Technology have arranged a joint conference on "Automatic Control in the Process Industries", to be held at the Caxton Hall, London, S.W.1, on October 4. Further particulars can be obtained from the General Secretary, Institution of Chemical Engineers, 56 Victoria Street, London, S.W.1. 